\title{
Instrumen Asesmen Berbasis Literasi Sains Tentang Materi Keanekaragaman Hayati
}

\section{Rizka Putri Alti ${ }^{*}$, Lufri2 ${ }^{2}$, Helendra ${ }^{3}$, Relsas Yogica ${ }^{4}$}

1,2,3,4 Jurusan Biologi, Universitas Negeri Padang, Padang, Sumatera Barat, Indonesia

\section{ART I CLE INFO}

\section{Article history}

Received February 10, 2021

Revised February 13, 2021

Accepted March 25, 2021

Available online April 25, 2021

Kata Kunci:

Instrument, Literasi Sains, Biologi

Keywords:

Instrument, Scientific Literacy,

Biology

\section{A B S T R A K}

Hasil penelusuran data penelitian PISA menunjukkan bahwa posisi literasi sains siswa Indonesia masih berada di peringkat 10 terakhir dibandingkan negara lainnya. Hal tersebut menunjukkan kurangnya keterampilan peserta didik Indonesia menyelesaikan soal PISA. Penelitian ini bertujuan untuk menghasilkan instrumen asesmen berbasis literasi sains tentang materi keanekaragaman hayat. Jenis penelitian ini yaitu penelitian pengembangan (Research and Development) dengan model pengembangan 4-D. Subjek penelitian terdiri dari 36 orang peserta didik kelas $X$ dan validator terdiri dari 3 orang dosen dan 1 orang guru. Instrumen yang digunakan dalam penelitian ini berupa lembar validasi. Jenis data dalam penelitian ini yaitu data kualitatif dan kuantitatif. Dalam penelitian pengembangan ini metode dan teknik analisis data yang digunakan adalah analisis deskriptif kualitatif dan kuantitatif. Hasil penelitian menunjukkan bahwa instrumen asesmen berbasis literasi sains yang sangat valid secara logis dengan persentase $90,54 \%$ dan valid secara empiris dengan rentangan $0,33-0,75$ untuk soal pilihan ganda, rentangan $0,42-0,80$ untuk uraian. Hasil penilaian kepraktisan oleh guru dengan persentase $93,88 \%$ dan oleh peserta didik dengan persentase $92,31 \%$. Hasil reliabilitas tinggi dengan rentangan 0,69$)$ ntuk soal pilihan ganda dan reliabilitas sangat tinggi dengan rentangan 0,86 untuk soal uraian. Berdasarkan hasil penelitian, dapat disimpulkan bahwa instrumen asesmen berbasis literasi sains tentang materi keanekaragaman hayati kelas dapat dikatakan layak untuk digunakan dalam proses pembelajaran.

\section{A B S T R A C T}

The results of the search for PISA research data show that the scientific literacy position of Indonesian students is still in the last 10 ranks compared to other countries. This shows the lack of skills of Indonesian students to solve PISA questions. This study aims to produce an assessment instrument based on scientific literacy on the subject of biodiversity. This type of research is research and development with a 4-D development model. The research subjects consisted of 36 students of class $X$ and the validator consisted of 3 lecturers and 1 teacher. The instrument used in this study was a validation sheet. The types of data in this study are qualitative and quantitative data. In the research, the methods and techniques of data analysis used were descriptive qualitative and quantitative analysis. The results showed that the scientific literacy-based assessment instrument was very valid logistically with a proportion of $90,54 \%$ and empirically valid with a range of 0,33-0,75 for multiplechoice, a range of 0,42-0,80 for description. The results of the practicality assessment by teachers with a proportion of $93,88 \%$ and by students with a proportion of $92,31 \%$. The reliability results with a range of 0,69) for multiple-choice questions and very high reliability with a range of 0.86 for the description of the questions. So, it can be said that scientific literacy-based instruments on biodiversity material can be said to be feasible to use in the learning process.

\section{Pendahuluan}

Posisi literasi sains siswa Indonesia menurut penelitian PISA oleh OECD diketahui berada di peringkat 10 terakhir dibandingkan Negara lainnya. Hal tersebut menunjukkan kurangnya keterampilan peserta didik Indonesia untuk menyelesaikan soal PISA. Pada soal literasi sains PISA, individu diuji kemampuan pengetahuan ilmiahnya untuk mengidentifikasi pertanyaan, menjelaskan fenomena ilmiah, dan menarik kesimpulan berdasarkan bukti dari masalah yang dipersoalkan (Afriana et al., 2016; Hapsari 
et al., 2019; Khayati \& Raharjo, 2020). Literasi sains berkaitan dengan kemampuan siswa dalam memahami informasi, ilmu pengetahuan dan fakta yang ada dalam kehidupan sehari-hari (Afriana et al., 2016; Puspitasari, 2015; Wen et al., 2020). Literasi sains tidak hanya menitikberatkan pada pengetahuan sains, tetapi juga keterampilan sains. Aspek keterampilan literasi sains antara lain keterampilan proses sains, pengambilan keputusan dalam isu-isu sosial ditinjau dari segi sains (socio scientific issue) serta pemecahan masalahnya (Ardianto \& Rubini, 2016; Septiani et al., 2019; Yuliati, 2017). Aspek keterampilan literasi sains tersebut hendaknya dilatih kepada siswa dalam pembelajaran sains di kelas.

Namun, pada kenyataannya dalam pelaksanaannya belum banyak sekolah menerapkan soal-soal yang mengaitkan dengan fenomena sehari-hari sehingga belum dapat digunakan untuk mengukur literasi sains siswa. Berdasarkan hasil observasi dan wawancara yang dilakukan, diketahui bahwa instrumen asesmen pembelajaran biologi belum sepenuhnya mengarah pada keterampilan bernalar dan berpikir kritis. Dalam ranah kognitif taksonomi bloom, rumusan soal yang melibatkan keterampilan bernalar dan berpikir kritis berada pada tingkatan C3 hingga C6. Hasil ini diperkuat oleh analisis melalui pedoman evaluasi instrumen terhadap soal ujian yang pernah dikembangkan oleh guru mata pelajaran biologi kelas $\mathrm{X}$ SMA. Distribusi tingkat kognitif soal ujian tengah semester I mata pelajaran biologi kelas X SMA dominan berada pada level C1 dan C2, seharusnya distribusi soal merata untuk semua tingkatan kognitif taksonomi bloom.

Berdasarkan angket respon oleh guru mata pelajaran biologi kelas X juga menunjukkan bahwa guru belum mengenal asesmen literasi sains serta masih asing dengan istilah literasi sains dan PISA. Hal ini disebabkan kurangnya informasi yang didapatkan oleh guru. Hal ini juga sejalan dengan penyebaran angket yang penulis lakukan terhadap 10 orang peserta didik kelas X diketahui belum pernah melakukan tes literasi sains PISA atau tes lain yang sejenisnya. Selain itu, diketahui pula bahwa soal-soal ujian yang digunakan belum memuat ketiga kompetensi literasi sains, soal-soal tersebut hanya memuat 15\% soal tentang menjelaskan fenomena ilmiah, sementara soal evaluasi dan merancang penyelidikan ilmiah, menafsirkan data dan bukti ilmiah tidak ditemukan sehingga soal tersebut belum memenuhi kriteria kompetensi literasi sains yang ditetapkan oleh PISA. Untuk 85\% soal lainnya merupakan soal-soal yang tidak masuk dalam kategori kompetensi literasi sains PISA.

Kondisi tersebut jika dibiarkan akan berdampak pada proses dan hasil pembelajaran di sekolah tersebut. Maka diperlukan solusi atas permasalahan tersebut. Salah satu upaya yang dapat dilakukan ialah dengan mengembangkan sebuah instrumen asesmen berbasis literasi sains yang dapat digunakan dan diadaptasi oleh guru untuk diterapkan dalam evaluasi pembelajaran. Pemilihan materi untuk mengembangkan soal-soal yang memenuhi kriteria ketercapaian literasi sains disesuaikan dengan kriteria yang ditetapkan PISA. PISA 2018 menilai pengetahuan ilmiah menggunakan konteks yang mengangkat permasalahan secara relevan yang dikategorikan menjadi lima aplikasi ilmu pengetahuan dan teknologi, salah satunya adalah biodiversitas atau keanekaragaman hayati (OECD, 2019). Belum banyak kajian mengenai pengembangan instrumen asesmen berbasis literasi sains pada materi biodiversitas.

Beberapa penelitian yang relevan dengan penelitian ini seperti penelitian yang dilakukan oleh (Fadillah, 2017) menemukan bahwa instrumen penilaian untuk mengukur keterampilan proses sains siswa SMA dikatakan layak ditinjau dari karakteristik standar tes. Kemudian penelitian yang dilakukan oleh (Supahar \& Prasetyo, 2015) menemukan bahwa instrumen yang dikembangkan dapat digunakan untuk meng- ukur kemampuan inkuiri mata pelajaran fisika siswa SMA. Kemudian penelitian lain juga menemukan bahwa instrumen tes berbasis literasi sains untuk memetakan critical thinking dan practical skills pada materi sistem peredaran darah dinyatakan valid secara teoritis maupun empiris (Khayati \& Raharjo, 2020). Tujuan penelitian ini untuk menghasilkan instrumen asesmen berbasis literasi sains tentang materi keanekaragaman hayati kelas X SMA.

\section{Metode}

Penelitian ini merupakan penelitian pengembangan yang dikembangkan berdasarkan tahapantahapan model 4D yang terdiri atas 4 tahap yaitu: Pendefinisian (define), Perancangan (design), Pengembangan (develop), Penyebaran (disseminate) (Tegeh \& Kirna, 2010). Tahap pendefinisian bertujuan untuk menetapkan dan mendefinisikan syarat-syarat yang dibutuhkan dalam pengembangan pembelajaran. Kegiatan yang dilakukan pada tahap ini meliputi analisis awal-akhir, analisis peserta didik, analisis soal ujian, dan analisis kurikulum. Tahap kedua adalah perancangan (design) dengan kegiatan yang dilakukan pada tahap ini adalah merancang instrumen asesmen berbasis literasi sains. Tahap selanjutnya iala tahap pengembangan (development). Tahap ini bertujuan untuk menguji validitas, praktikalitas, reliabilitas, tingkat kesukaran dan daya pembeda instrumen asesmen yang dikembangkan. Subjek penelitian terdiri dari 36 orang peserta didik kelas X SMAN 3 Pariaman dan validator terdiri dari 3 orang dosen FMIPA UNP dan 1 orang guru SMAN 3 Pariaman. Instrumen yang digunakan dalam penelitian 
ini berupa lembar validasi. Jenis data dalam penelitian ini yaitu data kualitatif dan kuantitatif. Dalam penelitian pengembangan ini metode dan teknik analisis data yang digunakan adalah analisis deskriptif kualitatif dan kuantitatif.

\section{Hasil dan Pembahasan}

Hasil dari penelitian pengembangan ini adalah sebuah produk instrument asisemen berbasis literasi sains tentang materi keanekaragaman hayati kelas X SMA yang dikembangkan berdasarkan tahapan-tahapan model pengembangan 4D dan telah melalui beberapa tahap uji coba serta sudah dilakukan revisi menurut saran dan kritik masukan yang diberikan. Proses pengembangan instrumen asesmen berbasis literasi sains tentang materi keanekaragaman hayati kelas X SMA ini terdiri atas 4 tahap yaitu: Pendefinisian (define), Perancangan (design), Pengembangan (develop), Penyebaran (disseminate).

Tahap pendefinisian bertujuan untuk menetapkan dan mendefinisikan syarat-syarat yang dibutuhkan dalam pengembangan pembelajaran. Kegiatan yang dilakukan pada tahap ini meliputi (1) analisis awal-akhir, (2) analisis peserta didik, (3) analisis soal ujian, dan (4) analisis kurikulum. Pada kegiatan analisis awal-akhir ini dilakukan untuk mengumpulkan informasi tentang permasalahan dalam asesmen pembelajaran. Kegiatan dimulai dengan pengisian angket oleh dua orang guru kelas X SMA Negeri 3 Pariaman pada bulan oktober 2020. Angket tersebut berisikan pertanyaan tentang asesmen yang digunakan oleh guru dan pengetahuan guru tentang literasi sains. Hasil analisis angket observasi guru diperoleh informasi bahwa kedua guru mata pelajaran biologi di sekolah tersebut belum sepenuhnya mengetahui istilah tentang literasi sains oleh PISA, padahal dalam kurikulum 2013 literasi sains menggunakan pendekatan ilmiah menuntut guru untuk mengembangkan literasi sains terhadap peserta didik. Kegiatan kedua yaitu analisis peserta didik. Kegiatan pada tahap ini yaitu observasi terhadap peserta didik kelas X SMA Negeri 3 Pariamana menggunakan angket observasi. Pertanyaan yang diajukan berupa soal-soal yang pernah dikerjakan peserta didik dan pengetahuan tentang literasi sains. Dari hasil analisis angket diketahui bahwa pada proses evaluasi pembelajaran asesmen yang digunakan masih berfokus pada soal-soal yang dominan bersifat hafalan, serta soal yang diujikan oleh guru di sekolah masih banyak pada kategori sedang. Hal ini menunjukkan bahwa asesmen yang digunakan dalam pembelajaran belum berbasis literasi sains, sehingga perlu dikembangkan asesmen berbasis literasi sains untuk meningkatkan kemampuan literasi sains peserta didik. Kegiatan ketiga ialah analisis soal ujian. Analisis soal ujian dilakukan untuk mengetahui soal ujian yang digunakan oleh sekolah. Dari hasil analisis soal ujian tengah semester I kelas X mata pelajaran biologi SMA Negeri 3 Pariaman tahun ajaran 2020/2021 diketahui bahwa asesmen yang digunakan belum sepenuhnya menerapkan instrumen berbasis literasi sains. Kemudian kegiatan terakhir ialah analisis kurikulum. Analisis kurikulum dilakukan sebagai dasar dalam merumuskan instrumen asesmen berbasis literasi sains tentang materi keanekaragaman hayati kelas X. Kegiatan ini dilakukan dengan cara meninjau kurikulum yang digunakan oleh sekolah. Hasil angket observasi terhadap guru, diketahui SMA Negeri 3 Pariaman sudah menerapkan kurikulum 2013.

Tahap kedua adalah tahap perancangan yang bertujuan merancang instrumen asesmen berbasis literasi sains. Tahap ini diawali dengan pemilihan aplikasi. Pemilihan aplikasi bertujuan untuk membantu memudahkan dalam tahap perancangan pembuatan instrumen asesmen. Perancangan instrumen dilakukan dengan menggunakan aplikasi Microsoft Office Word 2007. Komponen-komponen dalam instrumen ini meliputi cover luar, cover dalam, petunjuk pengerjaan instrumen, soal-soal, lembar jawaban, dan kunci jawaban yang dilengkapi dengan pedoman penskoran. Kemudian selanjutnya ialah pemilihan format. Pada tahap ini dilakukan pemilihan format untuk menyiapkan kerangka instrumen asesmen berbasis literasi sains untuk materi keanekaragaman hayati kelas X. Pemilihan format akan menentukan bentuk tampilan dari asesmen yang akan dikembangkan. Format yang dipilih harus menarik, jelas, tidak mengganggu dan memberikan kemudahan kepada peserta didik dalam menyelesaikan soal-soal berbasis literasi sains. Kegiatan selanjutnya ialah perancangan awal. Kegiatan yang dilakukan pada tahap perancangan awal meliputi hal-hal berikut ini diantaranya ialah (1) menganalisis KD sesuai dengan kompetensi literasi sains, (2) merancang kisi-kisi soal materi keanekaragaman hayati kelas X, (3) merancang butir soal sesuai dengan kisi-kisi soal materi keanekaragaman hayati kelas X, 4) mempersiapkan kunci jawaban.

Tahap ketiga adalah tahap pengembangan. Tahap ini bertujuan untuk menguji validitas, praktikalitas, reliabilitas, tingkat kesukaran dan daya pembeda instrumen asesmen yang dikembangkan. Hasil analisis validitas logis instrumen asesmen berbasis literasi sains dapat dilihat pada Tabel 1. 
Tabel 1. Hasil Analisis Validitas Logis Instrumen Asesmen Berbasis Literasi Sains.

\begin{tabular}{clcc}
\hline No. & Aspek Penilaian & Nilai Validitas (\%) & Kriteria \\
\hline 1. & Isi (Materi) & 88,97 & Valid \\
2. & Konstruksi & 90,41 & Sangat valid \\
3. & Bahasa & 91,40 & Sangat valid \\
4. & Teknik & 91,40 & Sangat valid \\
\hline & Rata-Rata & $\mathbf{9 0 , 5 4}$ & Sangat Valid \\
\hline
\end{tabular}

Berdasarkan data yang telah didapatkan dari hasil analisis validitas instrumen asesmen telah memenuhi kriteria valid dengan nilai rata-rata validitas yaitu 90,54\%. Adapun aspek penilaian validitas logis pada instrumen asesmen berbasis literasi sains ini yaitu aspek isi/materi, konstruksi, bahasa dan teknik. Aspek isi/materi untuk instrumen asesmen yang dikembangkan dinyatakan valid oleh validator dengan nilai validitas yaitu 88,97\%. Aspek konstruksi untuk instrumen asesmen yang dikembangkan dinyatakan sangat valid oleh validator dengan nilai validitas yaitu 90,41\%. Aspek bahasa, nilai validitas yang diperoleh yaitu 91,40\%. Ditinjau dari aspek teknik, nilai validitas yang diperoleh yaitu 91,40\%. Penilaian ini berkaitan dengan teknik penulisan yaitu jenis huruf yang digunakan, ukuran huruf, gambar, grafik dan juga tabel yang terdapat pada soal. Berdasarkan penilaian yang diberikan oleh validator menunjukkan aspek ini sudah tercapai. Uji praktikalitas instrumen asesmen dilakukan terhadap satu orang guru dan 36 peserta didik kelas X SMAN 3 Pariaman. Hasil analisis praktikalitas oleh guru dapat dilihat pada Tabel 2 dan hasil analisis praktikalitas oleh peserta didik dapat dilihat dalam Tabel 3.

Tabel 2. Hasil Analisis Praktikalitas Instrumen Asesmen Berbasis Literasi Sains oleh Guru.

\begin{tabular}{clcc}
\hline No. & \multicolumn{1}{c}{ Aspek Penilaian } & Nilai Praktikalitas (\%) & Kriteria \\
\hline 1. & Petunjuk Soal & 100,00 & Sangat Praktis \\
2. & Kemudahan Penggunaan & 94,44 & Sangat Praktis \\
3. & Keefektifan Waktu & 100,00 & Sangat Praktis \\
4. & Pemeriksaan & 100,00 & Sangat Praktis \\
5. & Ekuivalensi & 75,00 & Cukup Praktis \\
\hline \multicolumn{2}{c}{ Total } & $\mathbf{4 6 9 , 4 4 \%}$ & Sangat Praktis \\
\hline
\end{tabular}

Tabel 3. Hasil Analisis Praktikalitas Instrumen Asesmen Berbasis Literasi Sains oleh Peserta Didik

\begin{tabular}{clcc}
\hline No. & \multicolumn{1}{c}{ Aspek Penilaian } & Nilai Praktikalitas (\%) & Kriteria \\
\hline 1. & Petunjuk Soal & 91,66 & Sangat Praktis \\
2. & Kemudahan Penggunaan & 90,78 & Sangat Praktis \\
3. & Keefektifan Waktu & 93,05 & Sangat Praktis \\
4. & Ekuivalensi & 93,75 & Sangat Praktis \\
\cline { 1 - 1 } & Total & $\mathbf{3 6 9 , 2 4}$ & \multirow{2}{*}{ Sangat Praktis } \\
\hline
\end{tabular}

Berdasarkan hasil analisis data uji praktikalitas terhadap guru didapatkan nilai praktikalitas 93,88\% dengan kriteria sangat praktis. Sedangkan hasil analisis data uji praktikalitas terhadap peserta didik didapatkan nilai praktikalitas $92,31 \%$ dengan kriteria juga sangat praktis. Hal ini menunjukkan bahwa instrumen asesmen berbasis literasi sains sudah dapat digunakan sebagai instrumen asesmen pembelajaran di sekolah karena telah memiliki nilai praktis secara keseluruhan dari masing-masing aspek. Adapun aspek penilaian untuk uji praktikalitas terhadap guru dan peserta didik hampir sama, namun untuk guru ditambahkan aspek pemeriksaan. Secara keseluruhan aspek-aspek penilaian tersebut antara lain aspek petunjuk soal, kemudahan penggunaan, keefektifan waktu, pemeriksaan dan ekuivalensi. Ditinjau dari aspek petunjuk soal dinilai sangat praktis dengan nilai 95,83\%. Penilaian ini menunjukkan bahwa instrumen asesmen sudah dilengkapi dengan petunjuk soal yang jelas. Tes yang praktis adalah tes yang dilengkapi dengan petunjuk-petunjuk yang jelas sehingga dapat diberikan/diawali oleh orang lain (Aji \& Winarno, 2016; Arikunto, 2013; Lulu’ Aina'ul Mardhiyyah, Ani Rusilowati, 2016).

Aspek kemudahan penggunaan dinilai sangat praktis dengan nilai 92,61\%. Aspek keefektifan waktu dinilai sangat praktis dengan nilai 96,52\%. Hal ini dikarenakan soal yang diujicobakan berjumlah 20 soal dengan 4 bentuk soal dalam waktu 90 menit. Pengalokasian waktu yang diberikan pas untuk menyelesaikan soal-soal yang dikerjakan oleh peserta didik. Aspek pemeriksaan dinilai sangat praktis dengan nilai 100,00\%. Aspek ekuivalensi dinilai praktis dengan nilai 84,37\%. Artinya instrumen asesmen mudah untuk dilaksanakan. Mudah dilaksanakan misalnya tidak menuntut peralatan yang banyak dan 
member kebebasan kepada siswa untuk mengerjakan terlebih dahulu bagian yang dianggap mudah oleh siswa (Amalia \& Susilaningsih, 2014; Arif, 2016; Hamid, 2016).

Analisis butir soal dilakukan untuk memperoleh nilai validitas empiris, reliabilitas, tingkat kesukaran dan daya pembeda soal yang dikembangkan. Hasil analisis butir soal untuk masing-masing tipe soal dapat dilihat pada Tabel 4.

Tabel 4. Hasil Analisis Butir Soal Instrumen Asesmen Berbasis Literasi Sains dengan ANATES Versi 4.09

\begin{tabular}{ccccc}
\hline No. & Validitas Empiris & Reliabilitas & Daya Beda (\%) & Tingkat Kesukaran (\%) \\
\hline 1. & Valid $(0,33-0,75)$ & Reliabel $(0,69)$ Kategori Tinggi & Baik (100) & Sedang (50) \\
& & Reliabel $(0,86)$ Kategori Sangat $(10)$ & Cukup (30) & Sedang (60) \\
2. & Valid $(0,42-0,80)$ & Tinggi & Baik (70) & Mudah (30) \\
\hline
\end{tabular}

Keterangan: 1: Tipe Soal Pilihan Ganda; 2: Tipe Soal Uraian, Majemuk, dan Sikap

Berdasarkan hasil analisis validitas empiris terhadap soal pilihan ganda diperoleh 5 soal dengan kategori signifikan. Sedangkan untuk soal uraian, majemuk dan sikap diperoleh 7 soal yang signifikan. Data ni diperoleh dengan cara menganalisis butir soal yang diuji dengan menggunakan rumus korelasi product moment. Soal dikatakan signifikan apabila koefisien dari korelasi product moment lebih besar daripada ( $\mathrm{r}$ tabel). Perhitungan koefisien korelasi digunakan untuk mengukur tingkat validitas soal dan menentukan apakah soal tersebut layak digunakan atau tidak. Hal ini membuktikan tingkat pengecoh dari pilihan jawaban sudah tepat sehingga testee yang kemampuannya rendah tidak dapat menjawab dengan benar dan testee yang kemampuannya tinggi lebih banyak menjawab dengan betul. Sementara itu untuk tipe soal uraian, majemuk dan sikap juga menunjukkan tingginya persentase kategori daya pembeda yang baik (Aji \& Winarno, 2016; Riscaputantri \& Wening, 2018; Soesanto et al., 2016). Artinya hanya peserta didik yang memiliki kemampuan memahami pertanyaan dengan baik yang dapat memberikan jawaban dengan tepat.

Selanjutnya reliabilitas yang didapatkan dari instrumen asesmen yang dikembangkan adalah 0,69 (tinggi) untuk soal pilihan ganda dan 0,86 (sangat tinggi) untuk soal uraian, majemuk dan sikap. Daya pembeda soal yang telah diujikan di SMAN 3 Pariaman untuk soal pilihan ganda termasuk kategori (100\%) baik, sedangkan untuk soal uraian, majemuk dan sikap termasuk kategori (30\%) cukup, dan $(70 \%)$ baik. Berdasarkan analisis daya pembeda diketahui untuk tipe soal pilihan ganda memiliki nilai $(100 \%)$ baik artinya soal yang diujikan mampu membedakan antara testee yang berkemampuan tinggi dengan testee yang berkemampuan rendah. Berdasarkan analisis untuk tingkat kesukaran soal pada instrumen asesmen sudah bervariasi. Tipe soal pilihan ganda dari hasil analisis (50\%) kategori sedang dan (50\%) kategori mudah. Sedangkan untuk soal uraian, majemuk dan sikap yaitu (10\%) kategori sukar, $(60 \%)$ kategori sedang dan (30\%) kategori mudah. Berdasarkan hasil analisis tingkat kesukaran soal diperoleh informasi bahwa rata-rata butir soal yang dikembangkan adalah kategori sedang. Artinya, soal tidak terlalu mudah atau soal tidak terlalu sukar. Soal yang terlalu mudah tidak merangsang siswa untuk mempertinggi usaha memecahkannya, sebaliknya soal yang terlalu sukar akan menyebabkan siswa menjadi putus asa dan tidak mempunyai semangat untuk mencoba lagi karena di luar jangkaunnya (Fadillah, 2017; Lestari \& Setyarsih, 2020).

Beberapa penelitian yang relevan dengan penelitian ini seperti penelitian yang dilakukan oleh (Fadillah, 2017) menemukan bahwa instrumen penilaian untuk mengukur keterampilan proses sains siswa SMA dikatakan layak ditinjau dari karakteristik standar tes. Kemudian penelitian yang dilakukan oleh (Supahar \& Prasetyo, 2015) menemukan bahwa instrumen yang dikembangkan dapat digunakan untuk meng- ukur kemampuan inkuiri mata pelajaran fisika siswa SMA. Kemudian penelitian lain juga menemukan bahwa instrumen tes berbasis literasi sains untuk memetakan critical thinking dan practical skills pada materi sistem peredaran darah dinyatakan valid secara teoritis maupun empiris (Khayati \& Raharjo, 2020).

\section{Simpulan dan Saran}

Instrumen asesmen berbasis literasi sains tentang materi keanekaragaman hayati kelas X dapat dikatakan layak untuk digunakan dalam proses pembelajaran. Saran yang dapat disampaikan adalah agar guru dapat mengembangkan instrumen asesmen pada materi lainnya agar mampu mengoptimalkan pembelajaran.

\section{Daftar Rujukan}

Afriana, J., Permanasari, A., \& Fitriani, A. (2016). Project based learning integrated to stem to enhance 
elementary school's students scientific literacy. Jurnal Pendidikan IPA Indonesia, 5(2), 261-267. https://doi.org/10.15294/jpii.v5i2.5493.

Aji, B. S., \& Winarno, M. E. (2016). Pengembangan instrumen penilaian pengetahuan mata pelajaran pendidikan jasmani olahraga dan kesehatan (PJOK) Kelas VIII semester gasal. Jurnal Pendidikan, 1(7), 1449-1463. http://journal.um.ac.id/index.php/jptpp/article/view/6594.

Amalia, N. F., \& Susilaningsih, E. (2014). Pengembangan instrumen penilaian keterampilan berpikir kritis siswa SMA pada materi asam basa. Jurnal Inovasi Pendidikan Kimia, 8(2), 1380-1389. https://journal.unnes.ac.id/nju/index.php/JIPK/article/view/4443.

Ardianto, D., \& Rubini, B. (2016). Literasi sains dan aktivitas siswa pada pembelajaran IPA terpadu tipe shared. USEJ - Unnes Science Education Journal, 5(1), 1167-1174. https://doi.org/10.15294/usej.v5i1.9650.

Arif, M. (2016). Pengembangan Instrumen Penilaian Mapel Sains melalui Pendekatan Keterampilan Proses Sains SD/MI. Ta'allum: Jurnal Pendidikan Islam, 4(1). https://doi.org/https://doi.org/10.21274/taalum.2016.4.1.123-148.

Arikunto, S. (2013). Dasar-Dasar Evaluasi Pendidikan. Bumi Aksara.

Fadillah, E. N. (2017). Pengembangan Instrumen Penilaian Untuk Mengukur Keterampilan Proses Sains Siswa SMA. Jurnal Penelitian Pendidikan Biologi, 1(2), 123-134. https://doi.org/https://doi.org/10.32502/dikbio.v1i2.770.

Hamid, M. A. (2016). Pengembangan instrumen penilaian hasil belajar siswa berbasis tik pada pembelajaran dasar listrik elektronika. VOLT: Jurnal Ilmiah Pendidikan Teknik Elektro, 1(1), 37-46. https://doi.org/http://dx.doi.org/10.30870/volt.v1i1.822.

Hapsari, E. E., Sumantri, M. S., \& Astra, I. M. (2019). STRATEGI GURU MENINGKATKAN HASIL BELAJAR MENGGUNAKAN PENDEKATAN SAINTIFIK DI SEKOLAH DASAR. Jurnal Basicedu, 3(2), 850-860. https://doi.org/https://doi.org/10.31004/basicedu.v4i1.171.

Khayati, D. N., \& Raharjo, R. (2020). PENGEMBANGAN INSTRUMEN TES BERBASIS LITERASI SAINS UNTUKMEMETAKAN CRITICAL THINKING DAN PRACTICAL SKILLS SISWA PADA MATERI SISTEM $\begin{array}{llllll}\text { PEREDARAN DARAH XI KELAS } & \text { XI }\end{array}$ https://ejournal.unesa.ac.id/index.php/bioedu/article/view/36770.

Lestari, D., \& Setyarsih, W. (2020). Kelayakan Instrumen Penilaian Formatif Berbasis Literasi Sains Peserta Didik Pada Materi Pemanasan Global. Ipf: Inovasi Pendidikan Fisika, 09(03), 561-570. https://doi.org/https://doi.org/10.26740/ipf.v9n3.p561-570.

Lulu' Aina'ul Mardhiyyah, Ani Rusilowati, dan S. L. (2016). Pengembangan Instrumen Asesmen Literasi Sains Tema Energi. Journal of Primary Education, 5(2), 147-154.

OECD. (2019). PISA 2018 Results (Volume I): What Students Know and Can Do. In OECD Publishing: Vol. III. https://www.oecd.org/pisa/publications/PISA2018_CN_IDN.pdf.

Puspitasari, A. D. (2015). Efektifitas pembelajaran berbasis Guided Inquiry untuk meningkatkan literasi sains siswa. Jurnal Fisika Dan Pendidikan Fisika, 1(2), 1-5. https://doi.org/10.1017/CB09781107415324.004.

Riscaputantri, A., \& Wening, S. (2018). Pengembangan instrumen penilaian afektif siswa kelas IV sekolah dasar di Kabupaten Klaten. Jurnal Penelitian Dan Evaluasi Pendidikan, 22(2), 231-242. https://doi.org/10.21831/pep.v22i2.16885.

Septiani, D., Widiyawati, Y., \& Nurwahidah, I. (2019). Pengembangan Instrumen Tes Literasi Sains Berbasis Pisa Pada Aspek Menjelaskan Fenomena Ilmiah Untuk Siswa Kelas Vii. Science Education and Application Journal, 1(2), 46. https://doi.org/10.30736/seaj.v1i2.144.

Soesanto, G. R., Sihkabuden, S., \& Ulfa, S. (2016). Pengembangan instrumen penilaian kemampuan kognitif menggunakan kalimat efektif pada tunarungu tingkat SLTA. Jurnal Pendidikan: Teori, Penelitian, Dan Pengembangan, $1(6)$, 1169-1179. http://journal.um.ac.id/index.php/jptpp/article/view/6470/2749.

Supahar, S., \& Prasetyo, Z. K. (2015). Pengembangan Instrumen Penilaian Kinerja Kemampuan Inkuiri Peserta Didik Pada Mata Pelajaran Fisika Sma. Jurnal Penelitian Dan Evaluasi Pendidikan, 19(1), 96108. https://doi.org/10.21831/pep.v19i1.4560.

Tegeh, I. M., \& Kirna, I. M. (2010). Metode Penelitian Pengembangan Pendidikan. Universitas Pendidikan Ganesha.

Wen, C. T., Liu, C. C., Chang, H. Y., Chang, C. J., Chang, M. H., Fan Chiang, S. H., Yang, C. W., \& Hwang, F. K. (2020). Students' guided inquiry with simulation and its relation to school science achievement and scientific literacy. Computers and 1493830. https://doi.org/10.1016/j.compedu.2020.103830.

Yuliati, Y. (2017). Literasi Sains Dalam Pembelajaran Ipa. Jurnal Cakrawala Pendas, 3(2), 21-28. https://doi.org/10.31949/jcp.v3i2.592. 